
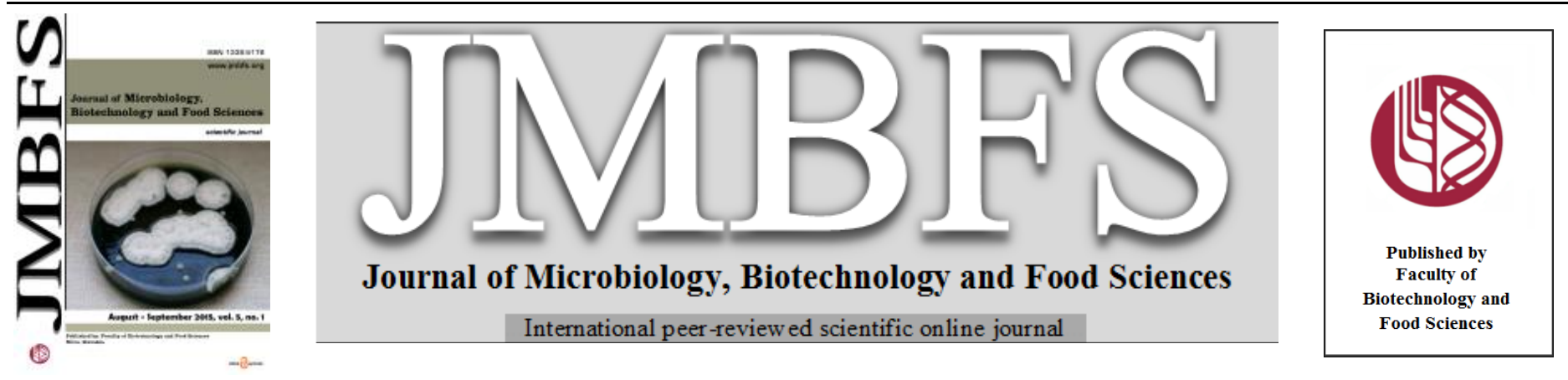

\title{
ISOLATION, SREENING AND OPTIMIZATION OF SUBMERGED CULTURE CONDITIONS FOR MYCELIAL BIOMASS PRODUCTION WITH ENHANCED ANTIBACTERIAL ACTIVITY OF THE FUNGUS MYROTHECIUM SPP. MRP001 AGAINST MULTI DRUG RESISTANT PATHOGENS
}

\author{
Mohammad Rizwan Pervez ${ }^{*}$, D. G. Bhadange ${ }^{2}$, Prashant V Thakare ${ }^{3}$, Mohammad Mussadiq ${ }^{4}$ \\ Address(es): Mohammad Rizwan Pervez C/o Dr. P. V. Thakare, \\ ${ }^{1}$ Department of Biotechnology, SGB Amravati University, 444602 and Amravati, Maharashtra, India phone number: 00919373153899 \\ ${ }^{2} \mathrm{Head}$, Department of Botany, Shri Shivaji College, Akot road, 444001 and Akola, Maharashtra, India. \\ ${ }^{3}$ Associate Prof., Department of Biotechnology, SGB Amravati University, 444602 and Amravati, Maharashtra, India. \\ ${ }^{4}$ Head and Associate Prof., Department of Microbiology and Biotechnology, Shri Shivaji College, Akot road, 444001 and Akola, Maharashtra, India.
}

*Corresponding author: biotechon@gmail.com

doi: 10.15414/jmbfs.2015.5.1.23-28

\section{ARTICLE INFO}

Received 2. 4. 2014

Revised 21. 4. 2015

Accepted 6. 5. 2015

Published 1. 8. 2015

Regular article OPEN $\bigodot_{\text {ACCESS }}$

\begin{abstract}
Fungi are interestingly; produce the bioactive natural products thus being screened for the production of valuable antibacterial product. In the present study the fungus was isolated from soil and identified as Myrothecium spp. MRP001 based on morphological characteristics and it was reinforced by 16S rRNA gene sequence analysis. The submerged culture conditions and nutritional requirements for the production of mycelial biomass with improved antibacterial activity were studied in shaker flask culture using OFAT (one factor at time) in six different media, After $120 \mathrm{~h}$ of growth, Tryptone Soya Broth (TSB) and Potato Dextrose Broth (PDB) shows maximum spore account $\left(2 \times 10^{8} \mathrm{CFU} / \mathrm{ml}\right)$ of Myrothecium spp MRP001. Among the all different culture media, the maximum biomass production of $2.14 \mathrm{~g} / \mathrm{L}$ and $2.23 \mathrm{~g} / \mathrm{L}$ were observed in Tryptone Soya Broth (TSB) and Potato dextrose broth (PDB) respectively, over a period of $120 \mathrm{~h}$ of incubation at $\mathrm{pH}$ of 6.5 in $25-30{ }^{\circ} \mathrm{C}$ in Myrothecium spp. Strain MRP001. Among the carbon sources, glucose supplemented basal medium showed an effective biomass production of $2.24 \mathrm{~g} / \mathrm{L}$. whereas in nitrogen sources, yeast extract had significant biomass production of $2.12 \mathrm{~g} / \mathrm{L}$. The optimized ethyl acetate extract of cultural filtrate showed a maximum inhibition zone of $28.4 \mathrm{~mm}$ and $26.3 \mathrm{~mm}$ against multidrug resistant $P$. aeruginosa strain 1 and $S$. aureus strain 5 , respectively. These results are useful for further investigation of the fungus in the future for microbial disease treatment for multi drug resistant human pathogens.
\end{abstract}

Keywords: Fermentation parameter, improved bioactivity, Myrothecium spp., multi drug resistant human bacterial pathogens

\section{INTRODUCTION}

Natural products play a major role in the discovery of leads for the development of drugs in the treatment of human diseases. Natural products are an unsurpassed source of bioactive compounds and constitute a relevant economic resource for the pharmaceutical, cosmetic and food industry. Since fungi live in a biologically competitive environment with unique physical and chemical parameters, such as $\mathrm{pH}$, temperature, pressure, oxygen, light, nutrients and salinity, the chemical diversity of the secondary metabolites and their range of applications from marine fungi is high (Debbab et al., 2010; Jiang $\boldsymbol{e t}$ al., 2013; Bhadury et al., 2013; Wu et al., 2013; Sun et al., 2012) .

Biopharmaceutical approach provide a unique environment for fungi and have been recognized as a repository of fungi with novel metabolites of pharmaceutical importance (Tan \& Zou, 2001; Strobel et al., 2004). Fungi are important resources for discovery of natural products. Fungi are producing important components of microbial diversity. Fungi represent an important and quantifiable component of fungal diversity, and are known to affect community diversity and structure (Krings et al., 2007). Fungi isolated from soil are more likely exhibit pharmaceutical potentials. Fungi have been found in soil sample examined, and it is estimated that there are over one million fungi existed in the nature (Petrini, 1991). Fungi provide a wide variety of structurally unique, bioactive natural products. These plentiful natural products represent a huge reservoir which offers an enormous potential for exploitation for medicinal, agricultural and industrial uses (Tan \& Zou, 2001, Zhang et al., 2006). There has been a great interest in fungi as potential producers of novel, biologically active products (Schulz et al., 2002, Strobel \& Daisy, 2003).The secondary metabolites produced by endophytes associated with medicinal plants can be exploited for curing diseases (Tejesvi et al., 2007). More exciting possibilities exist in the wild and unexplored part of the world for discovery of novel fungi, their biology, and their potential usefulness.

The potential application of the fungal species of Myrothecium spp., particularly in the prospect of bioactive compounds production, makes it more noteworthy to study the different cultural conditions that affect the growth of these microorganisms. In the present study, attempt was made to investigate the cultural conditions Myrothecium spp. for improved biomass production and antibacterial activity and fermentation process for high level production of bioactive compounds.

\section{MATERIAL AND METHODS}

\section{Source of bioactive compound producing fungus}

A soil sample was collected from local area at Akola, Maharashtra, India. Strain MRP001 was isolated from the sandy soil sample on starch-casein agar18 adjusted to $\mathrm{pH} 8.5(1 \mathrm{M} \mathrm{NaOH})$ and was preserved as a mixture of spores and mycelium fragments in glycerol $(20 \% \mathrm{v} / \mathrm{v})$ at $28^{\circ} \mathrm{C}$. The strain is deposited in the Microbial culture collection of the Department of Biotechnology at SGB Amravati University, Maharashtra, India. It was examined for chemotaxonomic and morphological properties known to be of value in Myrothecium systematic and by partial 16S rRNA gene sequence analysis in previous study (Rizwan $\boldsymbol{e}$ al., 2012).

\section{Cultivation and identification of fungal isolate}

The screening of microorganisms was done against various human pathogenic bacteria and antimicrobial activity found in isolated fungal strain was further confirmed to be Myrothecium spp. MRP001. The strain Myrothecium spp 
MRP001 which was used for this study was isolated from soil of PDKV region of Akola District. The stock culture of strain was maintained on a potato dextrose agar (PDA) slants. Slants were inoculated, incubated at $28{ }^{\circ} \mathrm{C}$ for 7 days and then stored at $4{ }^{\circ} \mathrm{C}$. The fungal isolate was identified to genus level at Molecular Biology Lab, Department of Biotechnology, SGB Amravati University, Amravati, Maharashtra, India and the bioactive compound producer MRP001 was identify as Myrothecium spp. using 16S rRNA sequence analysis (Rizwan et al., 2012).

\section{Effect of culture media}

The media requirements of fungus were determined by mycelial dry weight method (Jonathan 2002). Myrothecium spp. For effect of culture media on biomass production studies, MRP001 growth and antimicrobial production were evaluated in six different synthetic media after $96 \mathrm{~h}$ of incubation. Two millilitres of Myrothecium spp. MRP001 overnight culture were inoculated in $100 \mathrm{ml}$ of following synthetic media: Mueller Hilton (MH), Plate count broth (PCB), Tryptone Soya Broth (TSB), Rogosa and Sharpe (MRS), Potato dextrose broth (PDB) and Fred Waksman Basic 77 broth (WFB). The cultures were incubated for $96 \mathrm{~h}$ at $30{ }^{\circ} \mathrm{C}$ on rotary shaker $(120 \mathrm{rpm})$. Total counts, constituted by vegetative cells and spores, and were assessed after $96 \mathrm{~h}$ of incubation using Haemocytometer by the standard serial dilution method (Kobayashi et al., 1996 and Petrini et al., 1992). The experiments were done in triplicate.

\section{Effect of temperature and $\mathrm{pH}$}

The temperature and $\mathrm{pH}$ requirements of fungus were determined by mycelial dry weight method (Jonathan 2002). For temperature, potato dextrose broth (PDB) medium was dispensed into $500 \mathrm{ml}$ Erlenmeyer flasks $(200 \mathrm{ml}$ per flask). The flasks were autoclaved at $121^{\circ} \mathrm{C}$ for $20 \mathrm{~min}$. After cooling, each Erlenmeyer flask was inoculated with mycelia disc $(5.0 \mathrm{~mm}$ diameter $)$ from 6 day old culture and incubated at different temperatures $\left(20-40{ }^{\circ} \mathrm{C}\right)$ for $120 \mathrm{~h}$. All the experiments were done in triplicate. The mycelia were harvested using the method of (Jonathan 2002). For $\mathrm{pH}$, the same potato dextrose broth medium was employed but the medium was adjusted to $\mathrm{pH}$ values of 4.5-7.0. $200 \mathrm{ml}$ of each treatment was dispensed into $500 \mathrm{ml}$ Erlenmeyer flask and replicated three times.

\section{Effect of carbon and nitrogen sources}

The fungus was grown in basal liquid medium that was described by (Jin-zhong et al., 2003). The basal medium was supplemented separately with carbon sources $(15 \mathrm{~g} / \mathrm{L})$ such as glucose, fructose, maltose, cellulose, starch \& xylan. In the case of nitrogen $(10 \mathrm{~g} / \mathrm{L})$, various nitrogen sources such as ammonium nitrate, ammonium sulphate, potassium nitrate, sodium nitrate, calcium nitrate and yeas extract and the media were autoclaved. After cooling, each flask was inoculated with 5 agar discs $(5.0 \mathrm{~mm}$ size $)$ of 6 day old mycelium and incubated at $30^{\circ} \mathrm{C}$ for $120 \mathrm{~h}$ on rotary shaker $(120 \mathrm{rpm})$. The mycelial biomass were harvested and dried at $40{ }^{\circ} \mathrm{C}$ and weighed. Assessment of mycelial weight was carried out using the procedure described by (Kadiri \& Fasidi, 1994)

\section{Extraction of bioactive compounds}

Discs were cut from the edge of an actively growing colony on PDA with a flamed cork borer ( $5 \mathrm{~mm}$ diameter) and transferred aseptically into $500 \mathrm{ml}$ flasks containing optimized basal media containing glucose as carbon source $(15 \mathrm{~g} / \mathrm{L})$ and yeast extract as nitrogen source $(10 \mathrm{~g} / \mathrm{L})$. The culture was incubated for $120 \mathrm{~h}$ at $30^{\circ} \mathrm{C}$ and $\mathrm{pH}$ 6.5. After the incubation period, fungal mycelium was separated from the culture filtrate by muslin cloth. The filtrate and dried mycelium were extracted three times with ethyl acetate. The culture filtrate extract was concentrated by evaporation under reduced pressure at $45{ }^{\circ} \mathrm{C}$ using rotary vacuum evaporator. The dried extract was dissolved in $10 \%$ dimethyl sulfoxide (DMSO) and stored at $4{ }^{\circ} \mathrm{C}$ for further study.

\section{Antimicrobial activity}

\section{Test microorganisms}

The clinical strains of Staphylococcus aureus were obtained from skin infections and wounds of some patients, whereas strains of Pseudomonas aeruginosa were obtained from lung infections of cystic fibrosis patients from Government Clinical Laboratory, Main Hospital (District Akola, Maharashtra, India). All the clinical strains were stored in screw cap tube at $-20{ }^{\circ} \mathrm{C}$ in deep freezer. Staphylococcus aureus and Pseudomonas aeruginosa strains were identified by standard biochemical methods (Essers \& Radebold, 1980; Pourshadi \& Klaas, 1984).

\section{Susceptibility test}

The Kirby-Bauer disk diffusion test was used to determine the antibiotic resistance of $S$. aureus strains (1-10) and $P$. aeruginosa strains (1-8). The isolated colonies of the above strains from mother culture were inoculated into nutrient broth. The broth was incubated at $37{ }^{\circ} \mathrm{C}$ until it equals $0.5 \mathrm{McF}$ arland standards. A McFarland 0.5 turbidity standard corresponds to inoculums of $1 \times$ $10^{8} \mathrm{CFU} \mathrm{ml} / \mathrm{L}$ (Acar \& Goldstein, 1991). The antibiotic disks of methicillin (5 $\mu \mathrm{g} /$ disk $)$, penicillin (10 units/disk), and vancomycin $(30 \mu \mathrm{g} /$ disk) were used for clinical strains of $S$. aureus. Ciprofloxacin $(5 \mu \mathrm{g} / \mathrm{disk})$, cefotaxime (30 $\mu \mathrm{g} / \mathrm{disk})$ ofloxacin $(5 \mu \mathrm{g} /$ disk $)$, and amikacin $(30 \mu \mathrm{g} /$ disk $)$ were used for clinical strains of $P$. aeruginosa. Inoculated plates were inverted and incubated at $37{ }^{\circ} \mathrm{C}$ for $18 \mathrm{~h}$ After the incubation period, the diameter of zone of inhibition was measured, and results were interpreted according to the standards of Clinical and Laboratory Standards Institute (NCCLS 2008).

\section{Disk diffusion method}

The paper disk diffusion method was used to determine the antibacterial activity of isolated fungal extract (Acar \& Goldstein, 1996). Sterile disks (6 mm) were impregnated with $10 \mathrm{ml}$ of extract at a concentration of $1 \mathrm{mg} / \mathrm{ml}$. For bacteria, microorganisms were swabbed on the surface of Muller Hinton agar was used. Paper disks treated with $10 \%$ DMSO were used as negative controls. The plates were incubated at $37{ }^{\circ} \mathrm{C}$ for $18 \mathrm{~h}$ for bacteria. The diameter of the inhibition zone around each disk was measured at the end of the incubation time. Experiments were performed in triplicate and the antimicrobial activity was expressed as the average of inhibition zone diameters (in $\mathrm{mm}$ ) produced by the fungal extract.

\section{Statistical analysis}

The triplicate data are expressed as the mean value \pm standard error and presented in the form of figures. The error bars are depicted at 5\% limit. The overlapping and non-overlapping bars show non-significant and significant respectively differences among different treatments.

\section{RESULTS AND DISCUSSION}

\section{Morphological characteristics of Myrothecium spp. MRP001}

The morphological characteristic of isolated fungi was observed on PDA after 2 weeks of growth at $30{ }^{\circ} \mathrm{C}$. Colonies on PDA was circular, raised, at first white, later it was brown to reddish colour. Hyphae were thin walled and branched. Morphological characters of the fungus including sporodochia, conidiophores, conidiogenous cells and conidia, were observed with a Nomarski differential interference contrast optical system and a scanning electron microscope (SEM). For SEM, specimens were placed in fixative (3\% glutaraldehyde, $2 \%$ paraformaldehyde in $0.1 \mathrm{M}$ cacodylate buffer at $\mathrm{pH} 7.2$ ) at $4{ }^{\circ} \mathrm{C}$ for $24 \mathrm{~h}$. The specimens were washed three times for $20 \mathrm{~min}$ each in $0.1 \mathrm{M}$ cacodylate buffer, $\mathrm{pH} 7.2$, and then fixed $24 \mathrm{~h}$ with $1 \%$ osmium tetroxide in $0.1 \mathrm{M}$ cacodylate buffer. After three $20 \mathrm{~min}$ deionized water washes the samples were dehydrated in an ethanol series $(30 \%, 50 \%, 70 \%, 95 \%$, and $100 \%, 20$ min each, except $100 \%$ had three changes, two for $20 \mathrm{~min}$ and one overnight). The dehydrated samples were critical point dried (Polaron E3000). All specimens were attached to aluminum mounts on carbon tape, sputter coated with AuPd (Polaron E5100) and observed in the FESEM (Zeiss DSM982 Gemini Field Emission Scanning Electron Microscope). All of these properties are consistent with the classification of the strain in the genus Myrothecium spp., an assignment supported by the partial sequencing of the 16S rRNA gene.

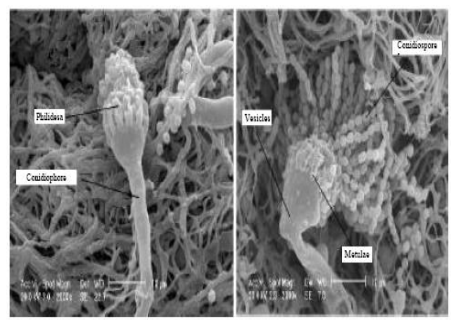

a. SEM of Myrothecium spp. Stain MRP001 spp. MRP001

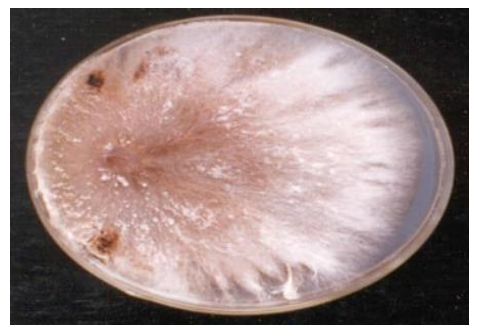

b. Myrothecium spp. Stain MRP001 on Potato dextrose agar
Figure 1 Morphological characteristics of Myrothecium spp. Stain MRP001. a. SEM of Myrothecium spp. Stain MRP001, b. Cultural morphology of Myrothecium spp. Stain MRP001 on PDA plate.

\section{Effect of various culture media on fungal biomass production}

To study the effect of culture media on biomass production, six different culture media were used. The fungal isolates was grown in Mueller Hilton (MH), Plate count broth (PCB), Tryptone Soya Broth (TSB), Rogosa and Sharpe (MRS), Potato dextrose broth (PDB) and Fred Waksman Basic 77 broth (WFB) of $\mathrm{pH} 6.5$ at $30^{\circ} \mathrm{C}$ for a period of $24,36,48,60,72,84,96,108$ and $120 \mathrm{~h}$. The maximum biomass production of $2.14 \mathrm{~g} / \mathrm{L}$ and $2.23 \mathrm{~g} / \mathrm{L}$ were observed in 
Tryptone Soya Broth (TSB) and Potato dextrose broth (PDB) respectively, over a period of $120 \mathrm{~h}$ in Myrothecium spp. Strain MRP001 (Figure 2).

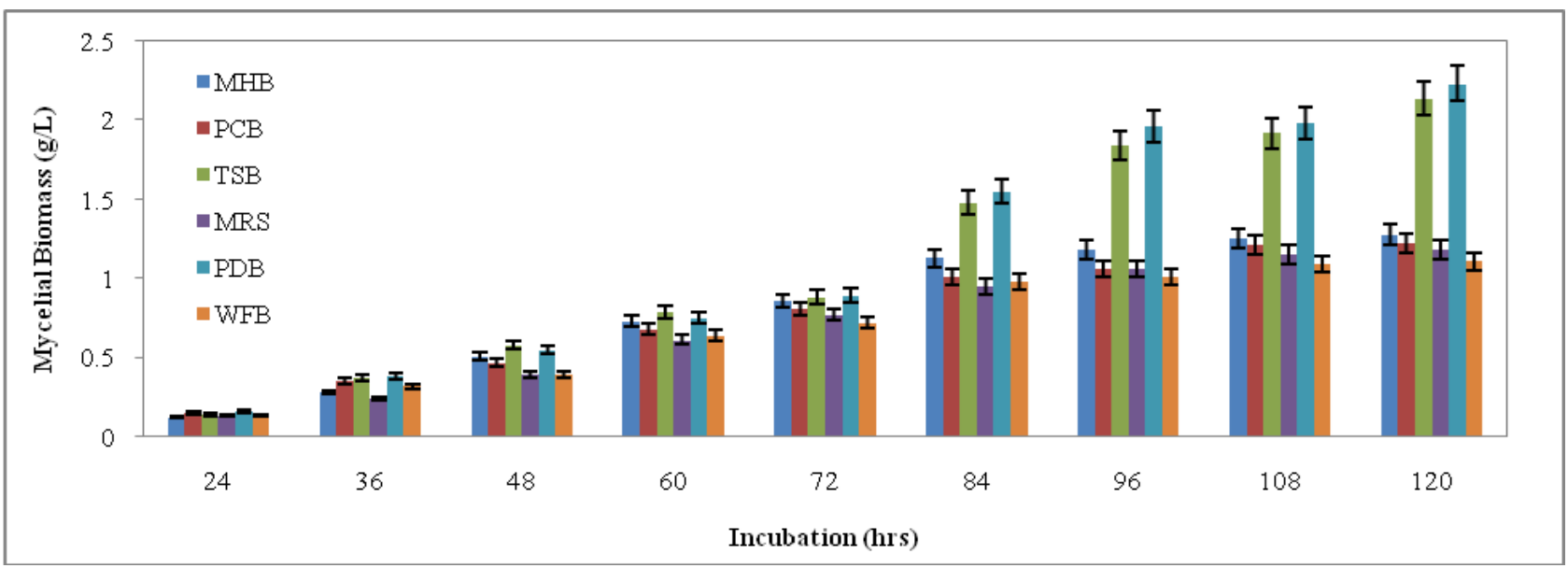

Figure 2 Effect of various culture media on biomass production of Myrothecium spp. Strain MRP001

\section{Effect of temperature and $\mathrm{pH}$ on biomass production}

The mycelia biomass of Myrothecium spp. Strain MRP001 was investigated at various temperatures $\left(15^{\circ} \mathrm{C}\right.$ to $\left.40{ }^{\circ} \mathrm{C}\right)$ in Potato dextrose broth at $\mathrm{pH}$ 6.5. The influences of temperature on the mycelia biomass of fungus was presented in Figure 3. The maximum biomass of $2.23 \mathrm{~g} / \mathrm{L}$ was observed at $25^{\circ} \mathrm{C}$ and $\mathrm{pH} 6.5$, whereas moderate mycelial biomass of $2.14 \mathrm{~g} / \mathrm{L}$ was observed at temperature 30 ${ }^{\circ} \mathrm{C}$ in $\mathrm{pH}$ 6.5. At $15^{\circ} \mathrm{C}$ there was no fungal growth was observed. The results indicated that the optimum temperature for maximal biomass production was 25 ${ }^{\circ} \mathrm{C}$ to $30{ }^{\circ} \mathrm{C}$ and the $\mathrm{pH}$ was 6.5 in Figure 4 .

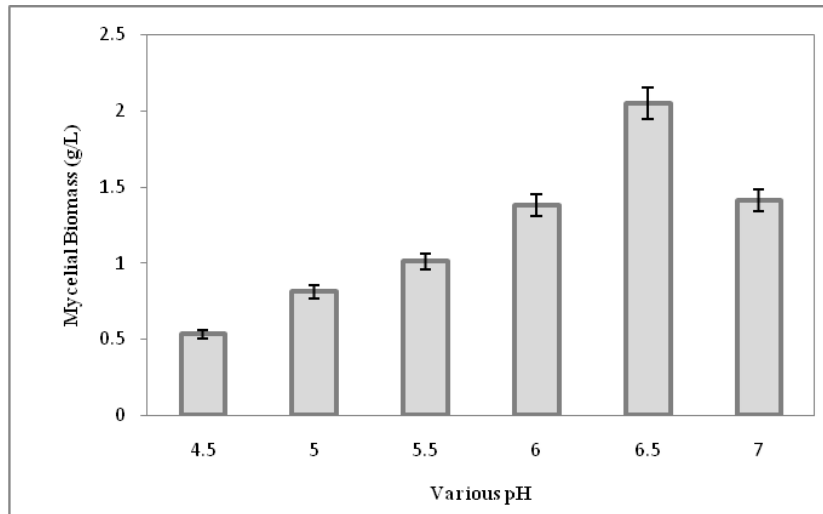

Figure 3 Effect of $\mathrm{pH}$ on biomass production of Myrothecium spp. Strain MRP001

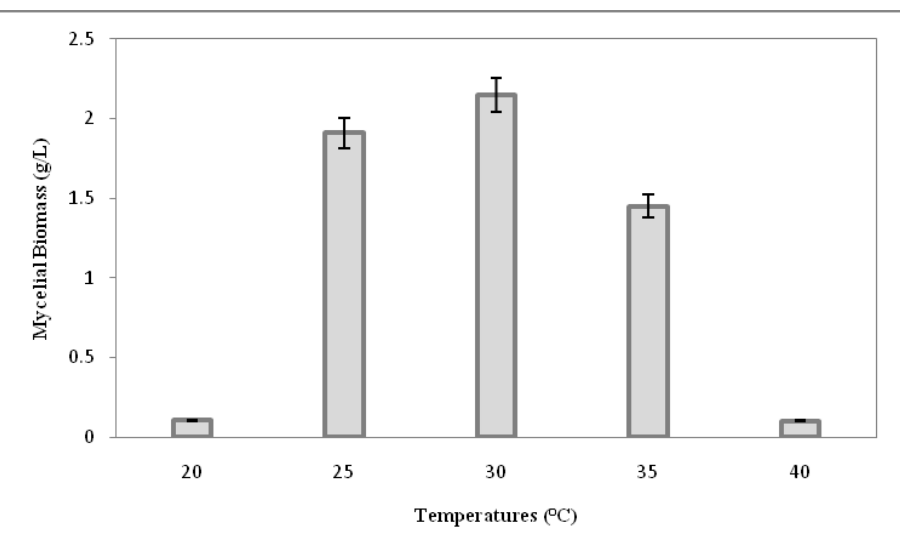

Figure 4 Effect of various temperature on biomass production of Myrothecium spp. Strain MRP001

\section{Effect of carbon and nitrogen sources on production of fungal biomass}

Myrothecium spp. Strain MRP001 was grown in basal growth medium of $\mathrm{pH} 6.5$ at $30{ }^{\circ} \mathrm{C}$ for $120 \mathrm{~h}$ to find out the suitable carbon sources for the maximum mycelial biomass production, various carbon sources were separately provided instead of glucose $(15 \mathrm{~g} / \mathrm{L})$ in the basal medium. Among the various carbon sources, glucose supplemented medium produced maximum biomass of $2.3 \mathrm{~g} / \mathrm{L}$. The other carbon sources produced the moderate mycelial biomass Figure 5.

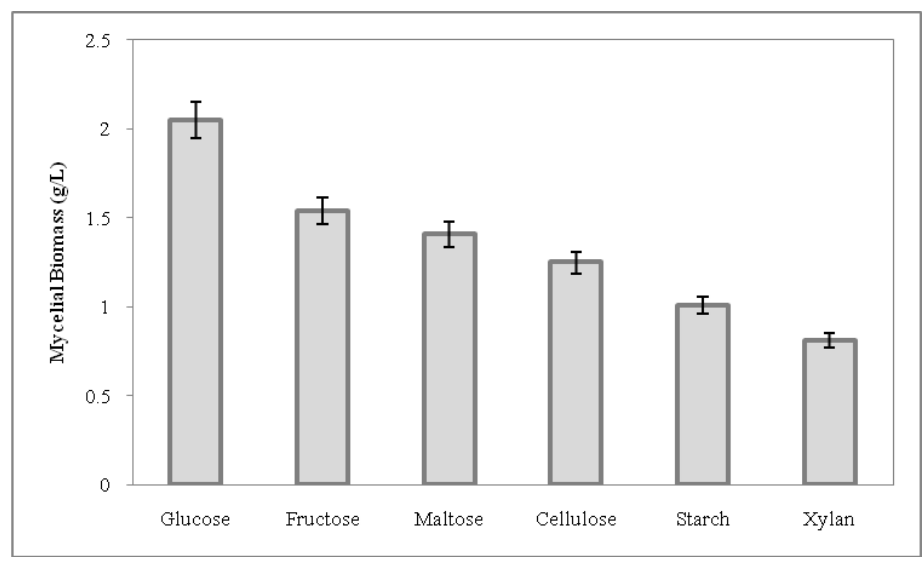

Figure 5 Effect of different carbon on biomass production of Myrothecium spp Strain MRP001

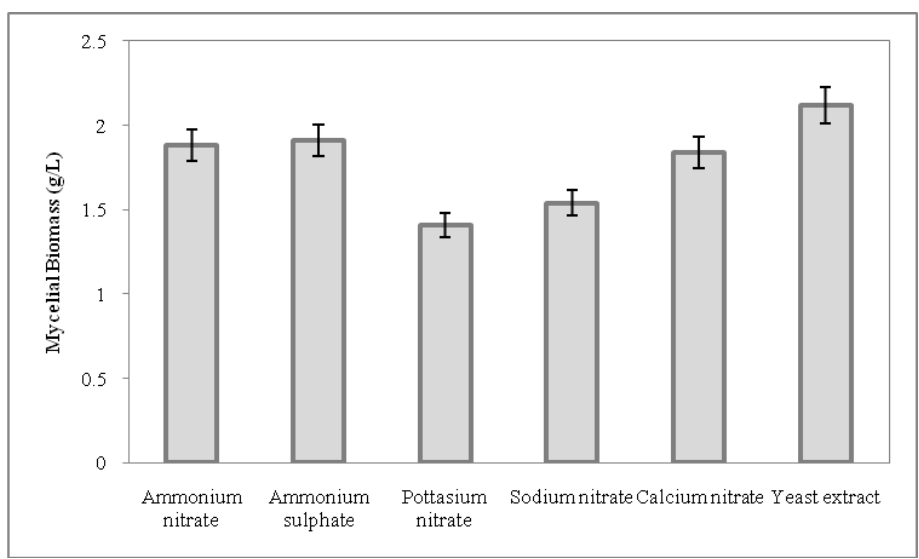

Figure 6 Effect of different nitrogen on biomass production of Myrothecium spp. Strain MRP001

To determine the effect of nitrogen sources on biomass production, various nitrogen sources were used. Among the nitrogen sources, yeast extract was found to be the best nitrogen source for the maximum production of biomass. Ammonium nitrate and ammonium sulphate were also produced an effective biomass. The maximum fungal biomass of $2.1 \mathrm{~g} / \mathrm{L}$ was observed on yeast extract supplemented medium in Figure 6 . After $120 \mathrm{~h}$ of incubation, the final $\mathrm{pH}$ of the medium was found to be 6.0 to 6.5 .

\section{Antibacterial Activity}

The clinical strains of $S$. aureus (1-10) were found to be positive for various biochemical tests such as the coagulase test, mannitol utilization test, DNase test, and catalase activity. The antibiotic resistance profile of $S$. aureus strains (1-10) was determined using commercial antibiotics such as methicillin, penicillin, and 
vancomycin. In contrast, $P$. aeruginosa (1-8) were identified by colony morphology, growth on cephaloridine fucidin centrimide agar, a positive oxidase test, and growth at $42{ }^{\circ} \mathrm{C}$. Antibiotics such as ciprofloxacin, cephotaxime ofloxacin, and amikacin were used to determine the resistance profile of $P$ aeruginosa strains (1-8). The optimized ethyl acetate extract of cultural filtrate showed a maximum inhibition zone of $28.4 \mathrm{~mm}$ and $26.3 \mathrm{~mm}$ against multidrug resistant $P$. aeruginosa strain 1, and $S$. aureus strain 5, respectively (Table 1).

Table 1 Antibacterial activity of optimized cultural filtrate extract of Myrothecium spp. against multidrug resistant S. aureus strains $(1-10)$ and P. aeruginosa strains $(1-8)$

\begin{tabular}{|c|c|c|c|c|}
\hline \multicolumn{5}{|c|}{ Zone of inhibition (mm) } \\
\hline S. aureus & Penicillin (10 unit/ml) & Methicillin $(10 \mu \mathrm{g} / \mathrm{ml})$ & Vancomycin $(30 \mu \mathrm{g} / \mathrm{ml})$ & Ethyl Acetate \\
\hline$P$. aeruginosa & CF $(5 \mu \mathrm{g} / \mathrm{ml})$ & CE $(30 \mu \mathrm{g} / \mathrm{ml})$ & OF $(5 \mu \mathrm{g} / \mathrm{ml})$ & Extract \\
\hline \multirow[t]{2}{*}{ Strain 1} & $12.5 \pm 0.15(\mathrm{R})$ & $10.8 \pm 0.14(\mathrm{R})$ & $16.5 \pm 0.08(\mathrm{~S})$ & $20.8 \pm 0.15$ \\
\hline & $13.5 \pm 0.4 \quad(\mathrm{R})$ & $12.4 \pm 0.4 \quad(\mathrm{R})$ & $12.5 \pm 0.35(\mathrm{R})$ & $27.5 \pm 0.45$ \\
\hline \multirow[t]{2}{*}{ Strain 2} & $12.8 \pm 0.14(\mathrm{R})$ & $11.2 \pm 0.31(\mathrm{R})$ & $15.4 \pm 0.28(\mathrm{~S})$ & $24.6 \pm 0.44$ \\
\hline & $20.6 \pm 0.1 \quad(S)$ & $22.5 \pm 0.14(\mathrm{~S})$ & $19.3 \pm 0.28(\mathrm{~S})$ & $13.5 \pm 0.15$ \\
\hline \multirow[t]{2}{*}{ Strain 3} & $14.2 \pm 0.28(\mathrm{R})$ & $12.1 \pm 0.16(\mathrm{R})$ & $16.0 \pm 0.22(\mathrm{~S})$ & $25.2 \pm 0.22$ \\
\hline & $15.4 \pm 0.28(\mathrm{R})$ & $14.9 \pm 0.14(\mathrm{R})$ & $13.5 \pm 0.4 \quad(\mathrm{R})$ & $27.6 \pm 0.33$ \\
\hline \multirow[t]{2}{*}{ Strain 4} & $11.5 \pm 0.35(\mathrm{R})$ & $10.2 \pm 0.31(\mathrm{R})$ & $17.2 \pm 0.14(\mathrm{~S})$ & $21.1 \pm 0.11$ \\
\hline & $23.7 \pm 0.23(\mathrm{~S})$ & $16.8 \pm 0.1 \quad(\mathrm{R})$ & $18.6 \pm 0.31(\mathrm{~S})$ & $22.7 \pm 0.30$ \\
\hline \multirow[t]{2}{*}{ Strain 5} & $11.8 \pm 0.14(\mathrm{R})$ & $8.9 \pm 0.22(\mathrm{R})$ & $18.5 \pm 0.28(\mathrm{~S})$ & $26.3 \pm 0.01$ \\
\hline & $23.3 \pm 0.04(\mathrm{~S})$ & $24.8 \pm 0.15(\mathrm{~S})$ & $19.5 \pm 0.14(\mathrm{~S})$ & $22.4 \pm 0.22$ \\
\hline \multirow[t]{2}{*}{ Strain 6} & $10.3 \pm 0.15(\mathrm{R})$ & $9.5 \pm 0.35(\mathrm{R})$ & $12.4 \pm 0.35(\mathrm{R})$ & $21.0 \pm 0.21$ \\
\hline & $22.3 \pm 0.15(\mathrm{~S})$ & $25.4 \pm 0.07(\mathrm{~S})$ & $18.4 \pm 0.28(\mathrm{~S})$ & $19.3 \pm 0.31$ \\
\hline \multirow[t]{2}{*}{ Strain 7} & $13.8 \pm 0.16(\mathrm{R})$ & $15.5 \pm 0.07(\mathrm{~S})$ & $16.9 \pm 0.14(\mathrm{~S})$ & $23.4 \pm 0.10$ \\
\hline & $17.5 \pm 0.22(\mathrm{R})$ & $23.7 \pm 0.18(\mathrm{~S})$ & $13.9 \pm 0.4 \quad(\mathrm{R})$ & $23.0 \pm 0.17$ \\
\hline \multirow[t]{2}{*}{ Strain 8} & $10.5 \pm 0.23(\mathrm{R})$ & $8.8 \pm 0.14(\mathrm{R})$ & $13.5 \pm 0.21(\mathrm{R})$ & $22.7 \pm 0.21$ \\
\hline & $18.7 \pm 0.14(\mathrm{R})$ & $16.5 \pm 0.35(\mathrm{R})$ & $16.5 \pm 0.14(\mathrm{~S})$ & $22.8 \pm 0.15$ \\
\hline Strain 9 & $15.0 \pm 0.21(\mathrm{R})$ & $12.2 \pm 0.10(\mathrm{R})$ & $14.8 \pm 0.22(\mathrm{R})$ & $20.4 \pm 0.13$ \\
\hline Strain 10 & $13.8 \pm 0.1 \quad(\mathrm{R})$ & $8.7 \pm 0.18 \quad(\mathrm{R})$ & $18.5 \pm 0.35(\mathrm{~S})$ & $22.6 \pm 0.22$ \\
\hline
\end{tabular}

Legend: R- Resistant and S - Sensitive, CF- Ciprofloxacin, CE- Cefotaxime, OF - Ofloxacin

\section{DISCUSSION}

\section{Identification fungal species of Myrothecium spp. Strain MRP001}

The fungal isolate of Myrothecium spp. Strain MRP001 could not be identified to a species level using available sequence data in Myrothecium database (BLASTN) and morphological characteristics. However, based on the morphological and sequence analysis, these isolates are found to be different species of Myrothecium, hence we have named as Myrothecium spp. Strain MRP001.

\section{Optimal culture conditions}

The growth profile of Myrothecium spp. Strain MRP001 included studies on mycelial biomass. The maximum growth in terms of mycelia production occurred on Potato Dextrose Broth (PDB) followed by Tryptone Soya Broth (TSB), while it was lowest on Fred Waksman Basic 77 broth (FWB). On the contrary, (Bilay et al., 2000) reported that Ganoderma lucidum had a slow growth rate in PDB medium, whereas there was a significant fungal biomass production in Mueller Hilton Broth (MHB). Similarly, the maximum fungal biomass production of Ganoderma species was observed in basal medium (Roberts 2004). The study of mycelial characteristics showed white, thick mat of fluffy growth on Potato dextrose broth while it was white thick mat of strand growth on Tryptone Soya Broth (TSB). At the same time, slow growth of slighty strandy mycelium was observed on Mueller Hilton Broth (MHB). The initial medium $\mathrm{pH}$ is a critica factor associated with the growth of fungi because it will affect the cell membrane function, cell morphology and structure, the solubility of salts, the ionic state of substrates, the uptake of various nutrients and product biosynthesis (Qing \& Jian, 2002). In this study, Myrothecium spp. Strain MRP001 was cultivated in the PDB and Tryptone Soya Broth (TSB) with different initial $\mathrm{pH}$ 4-7 and different initial temperatures $20-40{ }^{\circ} \mathrm{C}$, in culture conditions to investigate the effects of $\mathrm{pH}$ and temperature on mycelial biomass and antibacterial activity.

The results indicated that the optimum temperature and $\mathrm{pH}$ for maximal biomass production were 6.5 and $25{ }^{\circ} \mathrm{C}$ to $30{ }^{\circ} \mathrm{C}$ respectively. Earlier reports revealed that many kinds of fungi grow at acidic $\mathrm{pH}$ optima (Kim et al., 2003; Lee et al. 1999; Shu \& Lung, 2004). Similarly, (Lee et al., 2004) reported that the optimum $\mathrm{pH}$ was 5.5 for the maximum production of mycelial biomass of the fungus Grifola frondosa. The effect of temperature on mycelial production is comparable to the growth of many kinds of fungal species (Bae et al., 2000; Kim et al., 2003). Similarly, present results seem to be consistent with other reports in which the optimal temperature for fungal growth was $20{ }^{\circ} \mathrm{C}$ to $30{ }^{\circ} \mathrm{C}$ (Boddy, 1985; Lee et al., 2004; Lai et al., 2012).

\section{Optimal nutrient sources}

In general, mycelial cells of fungi grow over a broad range of carbon source (Burns et al., 1994). To determine the suitable carbon source for the production mycelial biomass with enhanced antibacterial compound in Myrothecium spp. Strain MRP001, six carbon sources were separately provided at the concentration of $15 \mathrm{~g} / \mathrm{L}$ instead of glucose employed in the basal medium. Among the carbon sources tested, glucose yielded the highest mycelial production. Medium containing glucose was significant in yielding the highest mycelia growth when compared to the other carbon sources. Similarly, (Xiaobo et al., 2006) reported that glucose, sucrose, yeast and peptone were supported more fungal biomass production in Xylaria sp. 2508. Glucose was found to be the best source for maximum biomass production in Lentinus edodes (Song \& Cho, 1987).

Nitrogen plays an important role in fungal growth and metabolite production (Kim et al., 2005). Thus, the effects of nitrogen on mycelial biomass production of Myrothecium spp. Strain MRP001in the form of ammonium nitrate ammonium sulphate, potassium nitrate, sodium nitrate, calcium nitrate and yeas extract were studied. Among the six nitrogen sources that have been tested in this study, yeast extract was most suitable for the growth of mycelial biomass (1.3 $\mathrm{g} / \mathrm{L}$ ). However, current findings are contrary to those of (Shih et al., 2006) that suggested most basidiomycetes prefer complex organic nitrogen sources for their favorable submerged cultures. The final $\mathrm{pH}$ of the medium remains in slightly acidic range. It is generally known that the byproduct of fungal metabolic process was acidic in nature (Fang \& Zhong, 2002).

\section{Antibacterial Activity}

Many fungi have a great potential for the production of useful bioactive metabolites and they are a prolific resource for drugs. The spectrum of pharmacological activities of fungi is fascinating. Discovery and evaluation of new bioactive compounds from various fungi as new safe compounds for the treatment of various diseases has become a hot research spot.

In present study, the antibacterial activity of the optimized ethyl acetate extract of culture filtrate was investigated against drug resistant pathogens. The antibiotic resistant profiles of $S$. aureus and $P$. aeruginosa strains were reported earlier (Ramesh et al., 2012). Maximum inhibition zone of $28.4 \mathrm{~mm}$ and $26.3 \mathrm{~mm}$ was observed against multidrug resistant $P$. aeruginosa strain 1 , and $S$. aureus strain 5, respectively. Similarly, (Iwalokun et al., 2007) reported that the petroleum ether and acetone extract of fungal species of Pleurotus ostreatus showed significant antibacterial activity against multidrug resistant $P$. aeruginosa.

\section{CONCLUSIONS}

Therefore, from the above results it can be concluded that it was possible to develop an optimized medium with regard to cultural conditions and nutritional 
sources to produce biomass of Myrothecium spp. Strain MRP001 with enhanced antibacterial activity against drug resistant human bacterial pathogens. High biomass was obtained in culture filtrate using the optimized medium with $15 \mathrm{~g} / \mathrm{L}$ of glucose and $10 \mathrm{~g} / \mathrm{L}$ of yeast extract as carbon and nitrogen sources respectively. To the best of our knowledge the nutritional requirements for a large scale submerged fermentation of Myrothecium spp. have not been demonstrated so far. Moreover, this is the first report concerning the highest biomass production obtained in submerged fermentation by the same species.

Acknowledgments: Authors thanks Department of Biotechnology, SGB Amravati University, Amravati, Maharashtra, India for financial support. I am thankful to Dr. D. G. Bhadange Sir for their support at Shri Shivaji College, Akola (MH) India. We thank Mr S. S. Adkar, Head of Research for assistance with the fermentation and Analytical studies at Pune, India, and for helpful discussions on the manuscript.

\section{REFERENCES}

ACAR, J.F., GOLDSTEIN, F.W. 1996. Antibiotics in laboratory medicine. In: Disk susceptibility test. (Lorian V, ed), Williams and Wilkins, Baltimore, MD, 151.

BAE, J.T., SINHA, J., PARK, J.P., SONG, C.H., YUN, J.W. 2000. Optimization of submerged culture conditions for exo-biopolymer production by Paecilimyces japonica. Journal of Microbiology and Biotechnology, 10, 482-487.

BHADURY, P., MOHAMMAD, B.T., WRIGHT, P.C. 2006. The current status of natural products from marine fungi and their potential as anti-infective agents Journal of Ind. Microbiol. Biotechnol., 33, 325-337. HTTP://DX.DOI.ORG/10.1007/S10295-005-0070-3

BILAY, V.T., SOLOMKO, E.F., BUCHALO, A.S. 2000. Growth of edible and medicinal mushrooms on commercial agar media. In Proc of the 15th In Congress Sci Cultivation of Edible Fungi. Vol. 1\&2 (Griensven LJLDV, ed), AA Balkema, Rotterdam, Maastricht, 757-761.

BODDY, L., GIBBON, O.M., GRUNDY, M.A.1985. Ecology of Daldinia concentrica: effect of a biotic variable on mycelial extension and interespecific interactions. Transactions of the British Mycological Society, 85, 201-211. HTTP://DX.DOI.ORG/10.1016/S0007-1536(85)80183-2

BURNS, P.J., YEO, P., KESHAVARZ, T., ROLLER, S., EVANS, C.S. 1994 Physiological studies of exopolysaccharide production from the basidiomycete Pleurotus sp. florida. Enzyme Microbial Technology, 16, 566-572 HTTP://DX.DOI.ORG/10.1016/0141-0229(94)90120-1

DEBBAB, A., ALY, A. H., LIN, W.H., PROKSCH, P. 2010. Bioactive compounds from marine bacteria and fungi. Journal of Microbial Biotechnology., 3, 544-563. HTTP://DX.DOI.ORG/10.1111/J.1751-7915.2010.00179.X

ESSERS, L., RADEBOLD, K. 1980. Rapid and reliable identification of Staphylococcus aureus by a latex agglutination test. Journal of Clinical Microbiology, 12, 641-643.

FANG, Q.H., ZHONG, J.J. 2002. Effect of initial pH on production of ganoderic acid and polysaccharide by submerged fermentation of Ganoderma lucidum Process Biochemistry, 37, 769-774. HTTP://DX.DOI.ORG/10.1016/S0032 9592(01)00278-3,

\section{HTTP://DX.DOI.ORG/10.1016/S0032-9592(02)00017-1}

IWALOKUN, B.A., USEN, U.A., OTUNBA, A.A., OLUKOYA, D.K. 2007. Comparative phytochemical evaluation, antimicrobial and antioxidant properties of Pleurotus ostreatus. African Journal of Biotechnology, 6, 1732-1739.

JIANG, W., Y.E., P., CHEN, T.A., WANG, K., LIU, P., HE, S., W.U.X., GAN, L., YE, Y. W.U.B. 2013. Two novel hepatocellular carcinoma cycle inhibitory cyclodepsipeptides from a hydrothermal vent crab-associated fungus Aspergillus clavatus C2WU. Marine Drugs, 11, 4761-4772. HTTP://DX.DOI.ORG/10.3390/MD11124761

JIN-ZHONG, W. CHEUNG, P.C.K, KSA-HING, W., NAIAN-LAI, H. 2003. Studies on submerged fermentation of Pleurotus tuber-regium (Fr.) Singer, part D physical and chemical factors affecting the rate of mycelial growth and bioconversion efficiency. Food chemistry 81, 389-393. HTTP://DX.DOI.ORG/10.1016/S0308-8146(02)00457-0

JONATHAN, S.G. 2002. Vegetative Growth Requirements and Antimicrobial activities of some higher fungi in Nigeria. Ph.D Thesis, University of Ibadan, Ibadan, Nigeria.

KADIRI, M., FASIDI, I.O. 1994. Growth requirements of Lentinus subnudus (Berk.), a Nigerian edible mushroom. Chemie, Mikrobiologie, Technologie der Lebensmittel, 16, 80-84.

KIM, H.O., LIM, J.M., JOO, J.H., KIM, S.W., HWANG, H.J. 2005 Optimization of submerged culture condition for the production of mycelial biomass and exopolysaccharides by Agrocybe cylindracea. Bioresource Technology 96, 1175-1182. http://dx.doi.org/10.1016/j.biortech.2004.09.021 KIM, S.W., HWANG, H.J., XU, C.P., SUNG, J.M., CHOI, J.W., YUN, J.W. 2003. Optimization of submerged culture process for the production of mycelial biomass and exo-polysaccharides by Cordyceps militaris C738. Journal of Applied Microbiology, 94, 120-126. HTTP://DX.DOI.ORG/10.1046/J.1365$\underline{2672.2003 .01754 . X}$
KOBAYASHI, H., NAMIKOSHI, M., YOSHIMOTO, T., YOKOCHI, T. 1996 A screening method for antimitotic and antifungal substances using conidia of $\mathrm{P}$. oryzae, modification and application to tropical marine fungi. Journal of Antibiotic. 49, 873-879. HTTP://DX.DOI.ORG/10.7164/ANTIBIOTICS.49.873 KRINGS, M., TAYLOR, T. N., HASS, H., KERP, H., DOTZLER, N. HERMSEN, E. J. 2007. Fungal endophytes in a 400-million-yr-old land plant: infection pathways, spatial distribution and host responses. New Phytologist., 174, 648-657. HTTP://DX.DOI.ORG/10.1111/J.1469-8137.2007.02008.X LAI, W.H., SALLEH, S.M., WONG, E.K., DAUD, .F, OTHMAN, A.M., SALEH, N.M. 2012. Optimization of submerged culture conditions for the production of mycelial biomass and exopolysaccharides from Lignosus rhinoceros. Fermentation Technology, 1, 107.LEE, B.C., BAE, J.T., PYO, H.B. CHOE, T.B., KIM, S.W., HWANG, H.J. 2004. Submerged fermentation conditions for the production of mycelial biomass and exopolysaccharides by the edible basidiomycete Grifola frondosa. Enzyme and Microbial Technology, 35, 369-76.

HTTP://DX.DOI.ORG/10.1016/J.ENZMICTEC.2003.12.015

LEE, K.M., LEE, S.Y., LEE, H.Y. 1999. Effect of ammonium phosphate on mycelial growth and exopolysaccharides production of Ganoderma lucidum in an air-lift fermenter. Journal of Microbiology and Biotechnology, 9, 726-731.

PETRINI, O., SIEBER, T.N., TOTI, L., VIRET, O. 1992. Ecology, metabolite production and substrate utilization in endophytic fungi. Nat. Toxins., 1, 185196. HTTP://DX.DOI.ORG/10.1002/NT.2620010306

PETRINI, O.1991. Fungal endophytes of tree leaves. In: Andrews, J. H., Hirano, S.S. (Eds.), Microbial Ecology of Leaves. Springer-Verlag, New York, USA, pp 179-197. HTTP://DX.DOI.ORG/10.1007/978-1-4612-3168-4_9

POURSHADI, M., KLAAS, J. 1984. Evaluation of latex agglutination and microtube coagulase tests for detection of Staphylococcus aureus. Diagnostic Microbiology and Infectious Disease 2, 287-291. HTTP://DX.DOI.ORG/10.1016/0732-8893(84)90059-2

QING, H.F., JIAN, J.Z. 2002. Effect of initial $\mathrm{pH}$ on production of ganoderic acid and polysaccharide by submerged fermentation of Ganoderma lucidum. Process Biochemistry, 37, 760-774.

RAMESH, V., KARUNAKARAN, C., RAJENDRAN, A. 2012. Evaluation of synergistic and antibacterial activity of Xylaria curta against drug resistant Staphylococcus aureus and Pseudomonas aeruginosa. Mycology, 3, 252-257.

RIZWAN, M.P., MUSADDIQ, M., THAKARE, P.V. 2012. In-Vitro Antimicrobial Studies of Isolated Myrothecium Spp Mrp001 against Human Pathogens. International Journal of Basic and Applied Medical Sciences, 2(3), 228-236.

ROBERTS, L.M. 2004. Australian Ganoderma identification, growth and antibacterial properties. PhD thesis. Swinburne University of Technology. Australia.

SCHULZ, B., BOYLE, C., DRAEGER, S., ROMMERT, A. K., KROHN, K. 2002. Endophytic fungi: a source of novel biologically active secondary metabolites. Mycological Research. 106, 996-1004 HTTP://DX.DOI.ORG/10.1017/S0953756202006342

SHIH, I.L., PAN, K., HSIEH, C. 2006. Influence of nutritional components and oxygen supply on the mycelial growth and bioactive metabolites production in submerged culture of Antrodia cinnamomea. Process Biochemistry, 41, 1129 1135. HTTP://DX.DOI.ORG/10.1016/J.PROCBIO.2005.12.005

SHU, C.H., LUNG, M.Y. 2004. Effect of $\mathrm{pH}$ on the production and molecular weight distribution of exopolysaccharide by Antrodia camphorata in batch cultures. Process Biochemistry, 39, 931-937. HTTP://DX.DOI.ORG/10.1016/S0032-9592(03)00220-6

SONG, C.H., CHO, K.Y. 1987. A synthetic medium for the production of submerged cultures of Lentinus edodes. Mycologia, 79, 866-876. HTTP://DX.DOI.ORG/10.2307/3807688

STROBEL, G., DAISY, B. 2003. Bioprospecting for microbial endophytes and their natural products. Microbiology and Molecular Biology Reviews. 67(4), 491-502. HTTP://DX.DOI.ORG/10.1128/MMBR.67.4.491-502.2003

STROBEL, G., DAISY, B., CASTILLO, U., HARPER, J. 2004. Natural products from endophytic microorganisms. Journal of Natural Products, 6, 257-268 HTTP://DX.DOI.ORG/10.1021/NP030397V

SUN, L., LI, D., TAO, M., CHEN, Y., DAN, F., ZHANG, W. 2012. Scopararanes $\mathrm{C}-\mathrm{G}$ : New oxygenated pimarane diterpenes from the marine sediment-derived fungus Eutypella scoparia FS26. Marine Drugs, 10, 539-550. HTTP://DX.DOI.ORG/10.3390/MD10030539

TAN, R. X., ZOU, W. X. 2001. Endophytes: a rich source of functional metabolites. Natural Product Reports. 18, 448-459. HTTP://DX.DOI.ORG/10.1039/B100918O

TEJESVI, M. V., KINI, K. R., PRAKASH, H. S., SUBBIAH, V., SHETTY, H. S. 2007. Genetic diversity and antifungal activity of species of Pestalotiopsis isolated as endophytes from medicinal plants. Fungal Diversity., 24, 37-54.

WU, B., WU, X., SUN, M., LI, M. 2013. Two novel tyrosinase inhibitory sesquiterpenes induced by $\mathrm{CuCl} 2$ from a marine-derived fungus Pestalotiopsis sp
Z233.
Marine
Drugs,
11 ,
2713-2721.

HTTP://DX.DOI.ORG/10.3390/MD11082713 
XIAOBO, Z., HAIYING, W., LINYU, H., YONGCHENG, L., HONGTAO, L. 2006. Medium optimization of carbon and nitrogen sources for the production of eucalyptene A and xyloketal A from Xylaria sp. 2508 using response surface methodology. Process Biochemistry, 41, 293-298. HTTP://DX.DOI.ORG/10.1016/J.PROCBIO.2005.06.002

ZHANG, H. W., SONG, Y. C., TAN, R. X. 2006. Biology and chemistry of endophytes. Natural Product Reports. 23, 753-771. HTTP://DX.DOI.ORG/10.1039/B609472B 